\title{
Efektivitas Kebijakan Dana Desa terhadap Pembangunan Infrastruktur
}

\author{
Irmansyah \\ Universitas Muhammadiyah Palopo \\ Irmansyah493@gmail.com \\ Sri Wahyuni Mustafa \\ Universitas Muhammadiyah Palopo \\ wahyuni_lecturer@umpalopo.ac.id \\ Rahmad Solling Hamid \\ Universitas Muhammadiyah Palopo \\ rahmadshamid@umpalopo.ac.id
}

\begin{abstract}
Abstrak Efektivitas Kebijakan Dana Desa Terhadap Pembangunan Infrastruktur di Desa Rompu Kecamatan Masamba Kabupaten Luwu Utara. Penelitian ini bertujuan untuk mengetahui bagaimana efektivitas kebijakan dana desa dalam pembangunan infrastruktur. Penelitian ini menggunakan pendekatan fenomenologi dengan paradigma interpretif sebagai payung penelitian, yaitu pendekatan yang menjabarkan kondisi atau ojek penelitian sebagaimana kejadiannya. Hasil penelitian ini menunjukkan bahwa, efektivitas dana desa dalam pembangunan infrastruktur di desa Rompu dinilai tepat. Diperoleh hasil yaitu tepat pelaksanaan, tepat target, tepat kebijakan dan tepak lingkungan. Dengan adanya kebijakan dana desa, masyarakat Rompu telah menerima dan menikmati manfaatnya, yakni akses masyarakat Rompu dalam sehari-hari lebih mudah, tepat pelaksanaan, bahwa pemerintah desa Rompu telah melakukan kerjasama yang baik dengan masyarakat, pemerintah kota/Kabupaten Luwu Utara dan pihak swasta. Tepat target, bahwa pembangunan yang dilakukan telah sesuai dengan target di APBDes. Tepat lingkungan, bahwa koordinasi yang dilakukan pemerintah desa Rompu dengan masyarakat dan pemerintah kota/Kabupaten Luwu Utara telah baik, serta dilingkungan eksternal kebijakan media massa telah memberikan informasi terkait pembangunan-pembangunan di Desa Rompu.
\end{abstract}

Kata Kunci Efektivitas kebijakan dana desa, Pembangunan infrastrukturr

\section{PENDAHULUAN}

Pembangunan merupakan salah satu hal yang penting yang menjadi permasalahan pokok di Indonsesia, terutama pedesaan. Masyarakat desa khususnya bagian terpencil sangat minim akan pembangunan karena belum adanya perhatian dari pemerintah. Berbicara tentang pembangunan desa, maka pasti tidak terlepas dengan adanya dana desa atau keuangan. Dengan adanya pembangunan infrastruktur yang 
tepat didalam sebuah desa dapat menambah keinginan masyarakat agar dapat lebih maju dan bisa bersaing dengan desa-desa lainnya agar bisa menjadi desa yang terbaik dimata negara. Dalam hal ini perlu adanya campur tangan pemerintah dan juga kepala desa yang cerdas dalam mengeluarkan kebijakan-kebijakan terhadap pengeluaran dana desa tersebut.

Dilihat dari fenomena sekarang ini mengenai dana desa, terdapat anggapan bahwa dana desa banyak disalah gunakan dalam hal pengalokasian. Hal tersebut dapat juga dilihat dari berbagai media surat kabar, televisi, radio, bahkan media lain seperti internet. Untuk mengantisipasi hal ini kita harus bijak dalam menelaah berita yang benar terjadi disebuah daerah. Baru-baru ini terjadi lagi yang marak diperbincangkan disosial media tentang dana desa yang digunakan oleh aparat desa untuk pernikahan menyebabkan banyak masyarakat yang terprovokasi dengan adanya pemberitaan tersebut. Masyarakat meminta kepada pihak berwajib untuk mengusut tuntas masalah ini karena bagi mereka dana di desa itu bukan milik pribadi melainkan digunakan untuk kepentingan masyarakat desa dan kepentingan bersama dalam membangun desa.

Hal ini sejalan dengan pemerintah mengesahkan undang-undang nomor 6 tahun 2014 tentang dana desa. Undang-undang ini mengatur kewenangan bagi pemerintah desa untuk menyelenggarakan urusan pemerintah dan kepentingan masyarakat setempat dalam sistem pemerintahan negara kesatuan republik Indonesia. Dalam undang-undang ini menjelaskan bahwa desa diberikan kesempatan untuk memperbaiki desanya sendiri dalam hal ini pembangunan infrastruktur agar masyarakat desa bisa lebih sejahtera dan maju. "dengan adanya dana desa setidaknya pembangunan infrastruktur harus lebih dinominalkan lebih besar agar dapat membantu masyarakat desa yang minim akan pembangunan tetapi alangkah baik juga harus memperhatikan pembangunan ekonomi yang kreatif seperti pembinaan terhadap petani'" Fhatimatuz Zehroil Batul (2018).

Tidak hanya dalam perhatian pemerintah terhadap desa semakin hari semakin meningkat, tetapi pasti ada juga desa-desa yang masih kurang pembangunannya, hal ini membuat masyarakat desa menjadi masa bodoh dan kurang inisiatif untuk membangun desanya menjadi berkembang dan sejahtera. Jika pembangunan desa terus terabaikan akan membuat masyarakat kurang berpartiipasi dalam hal pembangunan, mereka akan masa bodoh dan tidak mau melakukan apaapa. Kalau ini terus berlangsung maka pembangunan bukan saja tidak efektif, akan tetapi sasaran pembangunan tidak akan tercapai. Seperti yang dilihat dari kondisi diatas tidak terlepas dari orang nomor 1 disebuah desa akan tetapi dia juga dijadikan panutan oleh warganya. Pemimpin harus mencerminkan sikap dan moral yang baik bahkan etika. Masyarakat desa kebanyakan mengikuti moral kepala desanya tersebut dalam memimpin dan menjalankan tugas-tugas desa dengan benar dan tepat sasaran. Jadi berjalannya sebuah desa tersebut dilihat dari pemimpinnya, jika pemimpinnya cerdas dalam mengawai aparat-aparatnya dalam menjalankan tugas desa maka desa akan berkembang dan masyarakatnya juga sejahtera.

Terdapat pada salah satu desa di Luwu Utara yaitu desa Rompu kecamatan Masamba Kabupaten Luwu Utara. Didesa tersebut merupakan desa yang memiliki jumlah penduduk yang mayoritas petani. Dilihat dari masyarakat yang cerdascerdas tidak lupuk dari peran kepemimpinan kepala desanya dalam sebuah desa terdapat anggaran dana desa dan beliau beserta aparat desa lainnya mengalokasikan dana desa untuk pembangunan infrastruktur didesa tersebut. Dengan adanya dana desa peluang pembangunan lebih besar dalam hal ini memenuhi keinginan 
masyarakat. Meskipun didesa lain mungkin pembangunan infrastrukutur bukan keinginan atau kebutuhan utama mereka tetapi terkhusus masyarakat desa rompu lebih berfokus pada pembangunan fisik, karena akan membuka lapangan pekerjaan yang lebih banyak, contoh pembangunan fisik yaitu drainase, rabat beton, pengerasan jalan tani. "anggaran pemerintah yang diberikan kepada desa pada hakekatnya digunakan untuk meningkatkan pembangunan dan pemberdayaan masyarakat, Dana tersebut harus digunakan sebagai mestinya sesuai dengan keperluan setiap desa baik dalam hal pembangunan maupun pemberdayaan' Siti Zaki (2019).

Jadi dengan adanya pembangunan infrastruktur didesa tersebut menjadi salah satu mata pencaharian masyarakat desa karena banyak membuka lapangan pekerjaan karena dapat juga memberdayakan masyarakat setempat menjadi lebih sejahtera. Dari $100 \%$ kebijakan alokasi dana desa $70 \%$ untuk pembangunan infrastruktur dan 30\% untuk pemberdayaan masyarakat desa, contoh dari pemberdayaan masyarakat desa didesa rompu yaitu BUMDES dan pelatihan kelompok untuk masyarakat. Dampak yang dirasakan langsung oleh masyarakat yaitu dengan dikeluarkannya kebijakan desa tentang lebih memfokuskan pada pembangunan infrastruktur membuat masyarakat lebih terbantu misalkan dalam hal rabat beton, bisa mempermudah petani mengakses jalan dengan mudah. Kebujakan tersebut sejalan dengan keinginan masyarakat agar lebih memfokuskan pada pembangunan fisik sehinggah dapat bermanfaat dan banyak membuka lapangan pekerjaan. Hal ini dapat menjadikan masyarakat menjadi masyarakat desa yang sejahtera dan dapat membangun desanya menjadi desa yang sesuai dengan harapan setiap masyarakat desa. Hal ini sesuai dengan kebijakan pemerintah daerah Luwu Utara tentang penggunaan dana desa yang tepat sesuai dengan kebutuhan masingmasing daerah/desa dalam hal pembangunan infrastruktur maupun pemberdayaan masyarakat. Dalam kebijakan tersebut pemerintah memberikan kebebasan kepada desa untuk menentukan desanya sendiri dengan dana yang telah diberikan digunakan sebaik mungkin sehingga tepat sasaran. Dari hasil wawancara yang saya dapatkan bahwa kepala desa tidak terlalu memfokuskan dana desa pada pemberdayaan masyarakat karena warga di desa Rompu masih kurang mental untuk membuat suatu yang bisa menghasilkan. Sudah beberapa kali kepala desa memanggil pemateri untuk memberikan pelatihan untuk masyarakat disana akan tetapi awalnya saja yang diterima dengan baik tapi sesudahnya tidak dijalankannya lagi. Hal inilah yang membuat kepala desa untuk lebih memfokuskan pada pembangunan infrastruktur dibandingkan dengan pemberdayaan masyarakat. Di desa tersebut kepala desa siap mengalokasikan semua dana desa untuk pemberdayaan masyarakat jika memang masyarakatnya mau membuat suatu produk yang bisa mereka jadikan pendapatan selain hasil pertanian. Tapi sayangnya masyarakat desa disana kurang mental untuk bisa mewujudkan hal itu.

Pengelolaan alokasi dana desa dalam meningkatkan pembangunan non fisik juga perlu dalam sebuah desa akan tetapi, masyarakat yang masih kurang partisipasi dalam hal ini lebih mementingkan urusan pribadi dibanding harus ikut berpartisipasi dalam membangun desanya" Sholihatul Fitri (2019). Selain dalam hal pengalokasian kepala desa juga mengeluarkan kebijakan-kebijakan yang bisa melancarkan setiap urusan masyarakat desa tersebut, seperti kebijakan harus fleksibel artinya dimanapun, kapan pun beliau akan melayani masyarakatnya jika memang masih bisa dilayani seperti dalam hal tanda tangan berkas. Dan juga 
pelayanan harus cepat agar setiap urusan yang mendesak bisa dikerjakan secepatnya tanpa mengulir waktu lagi.

Hasil akhir yang diharapkan dalam penelitian ini dengan penggunaan dana desa yang tepat dapat meningkatkan pembangunan daerah baik itu pada bidang fisik maupun non fisik. Dari segi fisik meliputi pembangunan fasilitas desa seperti pembuatan rabat beton, aspal tani, drainase dan mushollah dan dari segi non fisik meliputi pemberdayaan masyarakat desa seperti badan usaha milik desa dan pelatihan bagi petani. Terkait hal tersebut maka terjadi permasalahan yang menarik untuk dibahas dan dikaji lebih dalam lagi mengenai efektivitas kebijakan dana desa terhadap pembangunan infrastruktur. Oleh karena itu, penelitian ini mengamati proses penggunaan dana didesa yang selama ini telah dilakukan apakah sudah sesuai dengan prosedur yang ada dan memiliki pengaruh terhadap pembangunan infrastruktur. Dimana alokasi dana desa merupakan hal utama dalam menunjang pembangunan desa dalam meningkatkan kesejahteraan masyarakat didesa Rompu. Adapun tujuan yang hendak dicapai dalam penelitian ini yakni untuk mendeskripsikan evektifitas kebijakan dana desa terhadap pembangunan infrastruktur di Desa Rompu Kecamatan Masamba Kabupaten Luwu Utara.

\section{LANDASAN TEORI}

\section{Desa}

Desa adalah kesatuan masyarakat hukum yang mempunyai susunan asli berdasarkan hak asal usul yang bersifat istimewa. Landasan pemikiran dalam mengenai pemerintahan desa adalah keanekaragaman, partisipasi, otonomi, demokratis dan pemberdayaan masyarakat. Undang-undang nomor 6 tahun 2014 tentang pemerintahan desa mengenai desa adalah desa dan desa adat atau yang disebut dengan nama lain, selanjutnya disebut desa dalah kesatuan masyarakat hukum yang memiliki batas wilayah yang berwenang untuk mengatur dan mengurus urusan pemerintahan, kepentingan masyarakat setempat berdasarkan prakarsa masyarakat, hak asal usul, hak tradisional yang diakui dan dihormati dalam sistem pemerintahan negara kesatuan republik Indonesia (NKRI).

\section{Alokasi Dana Desa}

Salah satu pendapatan desa yang diterima oleh desa yaitu APBdesa yaitu berupa alokasi dana desa yang bersumber dari dana perimbangan keuangan pusat dan daerah dan ditransferkan melalui kepala urusan keuangan desa. Dengan adanya alokasi dana desa, maka kebutuhan desa akan terpenuhi dalam hal pembangunan infrastruktur dan hal lainnya. Sesuai dengan peraturan pemerintah nomor 43 tahun 2014 mengenai desa, dimana penyelenggaraan pada urusan pemerintah desa didanai dari APB Desa dan bantuan pemerintah desa.

\section{Efektivitas}

Efektivitas pada dasarnya berasal dari kata efek dan digunakan dalam istilah ini sebagai hubungan sebab akibat. Efektivitas dapat dipandang sebagai suatu sebab dari variable lain. Efektivitas berarti bahwa tujuan yang telah direncanakan sebelumnya dapat tercapai karena adanya proses kegiatan. Menurut James L. Gibson dalam harbani pasolon (2008), mengatakan bahwa efektivitas adalah pencapaian sasaran dari upaya bersama. Efektifitas merupakan unsur penting untuk mencapai tujuan atau sasaran yang telah ditentukan didalam setiap organisasi, 
kegiatan atau proram. Disebut efektif apabila tercapai tujuan ataupun sasaran seperti yang telah ditentukan.

\section{Pembangunan}

Secara dinamis, pembangunan adalah suatu orientasi dan kegiatan usaha yang tanpa akhir. Proses pembangunan merupakan suatu perubahan sosial ekonomi. Pembangunan agar dapat menjadi suatu proses yang bergerak maju atau kekuatan sendiri tergantung kepada manusia dan struktur sosialnya. Pemabangunan juga dapat meningkatkan tingkat laju perekonomian baik suatu negara maupun suatu daerah/desa. Hal ini dapat merubah setiap struktur yang ada dalam pada perekonomiam. Penjelasan diatas sesuai dengan yang dikemukakan oleh Subandi (2011), proses pembangunan menghendaki adanya pertumbuhan ekonomi yang diikuti dengan perubahan dalam perubahan struktur ekonomi, dari pertanian ke industri atau jasa, perubahan kelembagaan, baik lewat regulasi maupun reformasi kelembagaan. Pembangunan secara berencana lebih dirasakan sebagai suatu usaha yang lebih rasional dan teratur bagi pembangunan masyarakat yang belum atau berkembang. Menurut Easton (2016) pembangunan merupakan upaya untuk meningkatkan taraf hidup serta merealisasikan potensi yang ada secara sistematis.

\section{METODOLOGI PENELITIAN}

Berdasarkan dari permasalahan penelitian, peneliti merasa bahwa metode penelitian kualitatif dengan pendekatan interpretif fenomenologi akan lebih banyak membantu peneliti untuk menemukan jawaban dari rumusan masalah. Pendekatan kualitatif yang digunakan dalam penelitian ini berimplikasi pada pendekatan interpretif fenomenologi yang mekanismenya secara konsisten dilakukan dari mulai pengelolaan data sampai dengan membuat kesimpulan tidak menggunakan perhitungan ataupun pengelolaan secara matematis dan statistik, melainkan lebih menekankan pada kajian interpretative atau analisis deskriptif. Penelitian ini menggunakan pendekatan fenomenologi dengan paradigma interpretif sebagai payung penelitian, yaitu pendekatan yang menjabarkan kondisi atau ojek penelitian sebagaimana kejadiannya. Lokasi penelitian dilakukan di Desa Rompu Kecamatan Masamba Kabupaten Luwu Utara.

Penelitian kualitatif dengan metode fenomenologi didasarkan pada falsafah, dimana peneliti berusaha untuk merumuskan suatu pertanyaan yang kemudian dianalisis berdasarkan pada pertanyaan persepsi partisipan mengenai fenomena yang sedang diteliti. Sumber data dalam penelitian ini yaitu Data primer adalah data yang diperoleh langsung dari lapangan atau tempat meneliti tanpa adanya prantara. Peneliti yang terjun langsung ke lapangan untuk melihat dan meninjau keadaan dan kondisi yang terjadi secara langsung di Desa Rompu Kecamatan Masamba Kabupaten Luwu Utara. Dan Data sekunder adalah data yang diambil dari berbagai macam sumber seperti buku harian, surat-surat pribadi, sampai dokumen resmi. Data sekunder juga didapat dari sumber kedua, dalam hal ini peneliti juga mengambil data dari dokumen penting yang sudah ada untuk memperkuat penelitian tersebut. Dokumen yang dimaksud berupa berkas berbentuk file yang sudah lama dan dimunculkan kembali untuk diteliti dan dijadikan bukti terhadap penelitian. Dalam teknik pengumpulan data ini, peneliti menggunakan 3 teknik yaitu wawancara, observasi, dokumentasi. Teknik analisi data pada penelitian ini yaitu teknik analisis deskriptif kualitatif dengan metode pemberian informasi dalam bentuk tulisan, yaitu menganalisa data dengan cara mendeskripsikan atau 
menggambarkan data yang telah terkumpul dan menyajikannya dalam bentuk teks tertulis hingga dapat ditarik kesimpulan mengenai masalah yang diteliti.

\section{HASIL PENELITIAN}

Dana desa merupakan dana yang bersumber dari APBN yang diperuntukkan untuk desa pertahunnya. Dana tersebut digunakan untuk pembangunan desa demi tercapainya pembangunan nasional. Setiap tahun, desa memperoleh Dana Desa hingga 1 (satu milyar). Dalam penggunaannya, 30\% dari Dana Desa digunakan untuk operasional sedangkan sisanya $70 \%$ digunakan untuk pembangunan. Dana Desa dinilai efektif apabila dana tersebut digunakan sesuai dengan tujuan dari adanya kebijakan Dana Desa sendiri. Dana Desa ada untuk mewujudkan pembangunan-pembangunan di Desa. Berdasarkan penelitian yang dilakukan mengenai Efektivitas Kebijakan Dana Desa Terhadap pembangunan Infrastruktur di Desa Rompu Kecamatan Masamba Kabupaten Luwu Utara, ditemukan beberapa informasi yang mampu menjelaskan bagaiamana Efektivitas Kebijkan Dana Desa Terhadap Pembangunan Infrastruktur di Desa tersebut. Untuk mengukur efektivitas dalam penelitian ini peneliti mengambil beberapa indikator dari pendapat Matlan (2008). Dalam memperoleh informasi peneliti menggunakan beberapa aspek yang akan dikaji yaitu meliputi: tepat kebijakan, tepat target, tepat pelaksana, tepat lingkungan.

\section{Tepat Kebijakan}

Tepat kebijakan dalam suatu efektivitas kebijakan dapat diartikan sebagai tolak ukur bagaimana suatu kebijakan tersebut dinilai apakah benar-benar diperlukan untuk publik (masyarakat) atau tidak. Seperti halnya dalam kebijakan pemerintah dalam mengesahkan undang-undang terkait tentang dana desa. Kebijakan tersebut dapat memecahkan masalah yang ada. Dengan demikian adanya kebijakan pemerintah terkait dana desa diukur dari ketepatan kebijakan, maka dana desa merupakan kebijakan yang dinilai tepat. Hal ini dibuktikan dengan adanya perubahan yang terjadi di Desa Rompu, pembangunan yang mulai digencarkan sudah bisa dirasakan dan dinikmati oleh masyarakat Desa Rompu, sehingga akses- akses tertentu yang dibutuhkan masyarakat bisa dengan mudah didapatkan.

Selain itu, dana desa dapat memberikan perubahan pembangunan untuk masyarakat Desa Rompu, dana desa dinilai tepat karena dana desa pada dasarnya merupakan kebijakan dibawah kewenangan langsung oleh kementrian desa atau KEMENDES. Pembangunan yang tertinggal dan transmigrasi-transmigrasi Republik Indonesia, dimana kemendes merupakan pemerintah indonesia tertinggi yang membidangi urusan pembangunan desa dan kawasan pedesaaan, pemberdayaan masyrakat desa, percepatan pembangunan daerah tertinggal dan transmigrasi. Adanya usaha pemerintah melalui pemerintah no 60 tahun 2014 tentang dana desa yang bersmber dari anggaran pendapatan dan belanja negara ini yag bertujuan terwujudnya pembangunan nasional, bangsa yang mandiri dan dapat memenuhi kebutuhan dari masyarakat itu sendiri.

\section{Tepat Pelaksanaan}

Indikator kedua dalam melihat suatu efektivitas kebijakan yaitu melihat apakah pelaksanaannya sudah tepat atau tidak. Ketepatan pelaksanaan dapat diartikan bagaimana kerjasama yang dilakukan oleh beberapa pihak. Pihak tersebut terdiri atas pemerintah, swasta dan masyarakat, maksudnya adalah bahwa implemmenter 
kebijakan bukan hanya dari pihak lembaga pemerintah saja, ketepatan pelaksanaannya melibatkan tiga pihak tersebut.

Dalam ketepatan pelaksanaan, implementer kebijakan dana desa ini dibagi atas tupoksi masing-masing dibidang pembangunan, meskipun tujuan dari dana desa adalah untuk mewujudkan pembangunan, namun pembangunan disini bukan diartikan sebagai pembangunan infrastruktur saja, pembangunan ini terdiri dari pembangunan infrastruktur dan pemberdayaan masyarakat. Pembangunan infrastruktur adalah pembangunan dalam bentuk fisik yang membantu dan mempermudah akses masyarakat dalam kegiatan sehari-hari, sedangkan pemberdayaan masyarakat adalah bagaimana masyarakat desa dapat dibina dan dibangun agar tercipta individu dan masyarakat yang mandiri. Pembangunan infrastrktur berupa pembangunan fisik melalui jalan, drainase, rabat beton, aspal tani, pembangunan masjid, pembuatan jembatan dan lainnya yang dibutuhkan masyarakat. Sedangkan pemberdayaan masyarakat berupa penyuluhan sosialisasi, pembelajaran topik tertentu yang dapat diaplikasikan masyarakat dalam kehidupan sehari-harinya. Sehingga dalam ketepatan pelaksanaannya, implementor dari dana desa diukur dari bagaimana kerjasama antara pemerintah desa, swasta dan masyarakat.

\section{Tepat Target}

Aspek ketiga yakni ketepatan target. Target merupakan suatu hal yang harus dicapai dalam suatu perencanaan. Ada dua hal yang dijadikan sebagai tolak ukur yaitu apakah target sesuai dengan yang direncanakan, kesiapan dari semua pihak serta ada atau tidaknya konflik bahkan harmoni, artinya yaitu, adakah sebuah penolakan atau tidak. Pertama, apakah target telah sesuai dengan apa yang direncanakan. Telah diketahui bahwa target dari adanya kebijakan terkait dana desa adalah pemerataan pembangunan. Di Desa Rompu sendiri tempat peneliti melakukan wawancara, pembangunan infrastruktur sangat diperlukan dalam membantu dan memudahkan warga dalam kegiatan sehari-harinya sehingga dengan melalui perencanaan yang dilakukan oleh pemerintah desa dan masyarakat Rompu dihasilkan beberapa target perencanaan pembangunan yang sudah sebagian terlaksanakan dan ada juga sebagian yang dibangun kedepannya yaitu pembangunan jalan, drainase, pembangunan masjid, pembuatan jembatan, pembuatan beronjong, pembuatan rabat beton, pembuatan aspal tani, pembuatan gorong-gorong.

Tolak ukur kedua dalam melihat ketepatan target adalah bagaimana kesiapan dari semua pihak serta ada atau tidaknya konflik bahkan harmoni. Artinya adalah bagaimana penerimaan kepada masyarakat Rompu dengan adanya kebijakan dana desa ini. Penerimaan tersebut maksudnya adalah apakah masyarakat Rompu mendukung atau menolak pembangunan yang akan dilakukan. Akan tetapi, dalam keberjalanan kebijakan dana dess ini menunjukkan hasil positif. Menurut informasi yang diperoleh oleh peneliti menunjukkan bahwa pihak-pihak yang ada di Desa Rompu termasuk masyarkat yang mendukung terkait pembangunan yang akan dilakukanan, Dari pernyataan diatas diketahui bahwa masyarakat Desa Rompu sangat mendukung dengan pembangunan-pembangunan yang ada di Desa Rompu. Tidak ada konflik dalam perencanaan maupun pelaksanaan, dukungan masyarakat ini membuat pelaksanaan pembangunan juga lancar dan lebih cepat terlaksana. 


\section{Tepat Lingkungan}

Aspek keempat dalam mengukur efektivitas kebijakan dana desa di Desa pandak adalah ketepatan lingkungan, yaitu lingkungan kebijakan dan lingkungan eksternal kebijakan.

a. Lingkungan kebijakan

Lingkungan kebijakan disini dimaksudkan bagaimana interaksi anatara lembaga perumus kebijakan dan pelaksana kebijakan yang berarti pemerintah pusat dengan pelaksana kebijakan yang berarti pemerintah daerah dan pemerintah desa, artinya bagaimana interaksi pemerintah Desa Pandakdengan pemerintah daerah dalam penelitian yang dilakukan melalui koordinasi dan monitoring.Koordinasi yang dilakukan adalah desa diberikan kewenangan untuk menyusun anggaran dana desa yang dimulai dari 2015 hingga tahun-tahun selanjutnya dalam pencairan dana desa, yang kemudian dikumpulkan kepemerintah daerah yaitu dinas pemberdayaan masyarakat dan desa Kabupaten Luwu Utara. Setelah tahap tersebut baru diajukan kepemrintah pusat, sedangkan monitoring yang dilakukan dari dinas pemberdayaan masyarakat dan desa Kabupaten Luwu Utara dan Kecamatan Masamba langsung kepada pelaksana pembangunan di Desa Rompu.

b. Lingkungan Eksternal Kebijakan

Lingkungan kedua dalam melihat ketepatan lingkungan dalam efektivitas dana desa di Desa Rompu adalah lingkungan eksternal kebijakan. Artinya, yaitu lingkungan yang ada diluar kebijakandana desa. Jika lingkungan kebijakan merupakan interaksi antar pemerintah pusat, daerah dan desa, maka berbeda dengan lingkungan eksternal kebijakan ini. Lingkungan eksternal kebijakan terdiri atas persepsi masyarakat, interpretasi masyarakat. Adanya dana desa membuat perubahan pembangunan di Desa Rompu. Masyarakat menyambut baik dan mendukung adanya kebijakan ini, karena dengan adanya kebijakan dana desa ini, Desa Rompu mengalami perlahan-perlahan perubahan pembangunan. Dalam ketepatan lingkungan dana desa di Desa Rompu dinilai telah tepat, ditunjukkan dari penelitian dan penjelasan diatas bahwa lingkungan kebijakan dan lingkungan eksternal kebijakan meliputi interkasi dengan pemerintah pusat, daerah, desa dan masyarakat serta kelompok kepentingan lainnya seperti media massa.

\section{KESIMPULAN}

Berdasarkan hasil penelitian pada bab sebelumnya, maka dapat diambil kesimpulan bahwa, evektifitas dana desa di Desa Rompu, Kecamatan Masamba, Kabupaten Luwu Utara dilhat dari dimensi evektifitas, diperoleh hasil bahwa efektivitas kebijakan dana desa terhadap pembangunan infrastruktur disewa Rompu itu bisa dikatakan sudah tepat. Dilihat dari kondisi masyarakat sekarang yang sudah mulai membaik dari segi pendapatan, dikarenakan akses jalan untuk keluar masuk sudah diperbaiki oleh pemerintah desa setempat. Selanjutnya kepala desa mengalokasikan dana desa sebanyak 70\% untuk pembangunan infrastruktur dan 30\% untuk pemberdayaan masyarakat. Hal itu dikarenakan masyarakat desa Rompi lebih membutuhkan pembangunan dibandingkan dengan pemberdayaan.

\section{penulis}

Berdasarkan dari hasil penelitian yang telah dilakukan maka saran yang

berikan yaitu pertama, bagi pemerintah desa, penggunaan dana desa sebaiknya tidak terlalu besar dalam pembangunan infrastruktur saja, tetapi juga harus memperhatikan pemberdayaan masyarakat desanya yang mayoritas masyarakat petani, sehingga mereka dapat memiliki produk mereka sendiri hasil pertanian 
mereka. Kedua, bagi Dinas Pemberdayaan Masyarakat agar lebih memperhatikan masyarakat dalam hal pemberdayaan dan juga harus melakukan lebih sering pendampingan dalam pelaksanaan kebijakan dana desa dan identifikasi di potensi desa. Sehingga pemberdayaan masyarakat di Desa Rompu juga bisa berjalan lancar dengan semestinya.

\section{DAFTAR PUSTAKA}

Asri, G. J. (2018). Efektivitas Pengelolaan Dana Desa Dalam Pembangunan Infrastruktur Desa Di Desa Bejagung Kecamatan Semanding Kabupaten Tuban Jawa Timur. Universitas Muhammadiyah Malang.

Atmadja, A.T. (2013). Pergulatan Metodologi Dan Penelitian Kualitatif Dalam Ranah Ilmu Akuntansi. Akuntansi Profesi, 3(2),122-141.

Batul, F. Z. (2018). Efektivitas Kebijakan Dana Desa Dalam Meningkatkan Pembangunan Di Desa Tegalrejo Kecamatan Gondang Kabupaten Sragen. Universitas Sebelas Maret.

Boedijono, Wicaksono, G., Puspita, Y., Bidhari, S. C., Kusumaningrum, N. D., \& Asmandani, V. (2019). Efektifitas Pengelolaan Dana Desa Untuk Pembangunan Dan Pemberdayaan Masyarakat Desa Di Kabupaten Bondowoso. Jurnal Riset Manajemen Dan Bisnis (JRMB) Fakultas Ekonomi, 4(1), 9-20.

Damayanti, W. (2018). Transparansi dan Akuntabilitas Pemerintah Desa Dalam Pengelolaan Alokasi Dana Desa. Jurnal Ilmu Dan Riset Akuntansi, 5, 15.

Darson, Kambolong, M., \& Suriyani. (2018). Efektivitas Pengelolaan Alokasi Dana Desa Dalam Meningkatkan Pelaksanaan Pembangunan (Studi Kasus Pada Desa Pola Kecamatan Pasir Putih Kabupaten Muna). 1-10.

Dethan, M. A. (2019). Efektivitas Pengelolaan Alokasi Dana Desa (ADD): Suatu Pendekatan Teoritis.Jurnal Akuntansi, 7(1), 15- 19.

Diana, M. (2008). Pengaruh Kepemimpinan Camat Terhadap Peningkatan Partisipasi Masyarakat Dalam Pembangunan.

Erawati, I., Darwis, M., \& Nasrullah, M. (2017). Efektivitas Kinerja Pegawai pada Kantor Kecamatan Pallangga Kabupaten Gowa. Jurnal Office, 3(1)

Fahri, L. N. (2014). Pengaruh Pelaksanaan Kebijakan Dana Desa terhadap Manajemen Keuangan Desa dalam Meningkatkan Efektivitas Program Pembangunan Desa. Jurnal Publik, 11(1), 75-88.

Fitri, S. (2019). Efektivitas Pengelolaan Anggaran Alokasi Dana Desa Terhadap Kualitas Pembangunan Daerah Dan Otonomi Daerah Di Desa Madumulyorejo Kecamatan Dukun Kabupaten Gresik. Universitas Islam Negeri Sunan Ampel.

Hutami, A. S. S. (2017). Analisis Pengelolaan Alokasi Dana Desa (ADD)Di Desa Abbatireng Kecamatan Gilireng, Kabupaten Wajo. Universitas Hasanuddin Makassar.

Juliana, E. (2017). Efektivitas Pemanfaatan Dana Desa dalam Menunjang Pembangunan Pedesaan di Kabupaten Asahan. Universitas Sumatera Utara.

Kambey, E. (2014). Efektivitas Penggunaan Dana Desa Dalam Pelaksanaan Pembangunan Di Desa Karegesan Kecamatan Kautidan Kabupaten Minahasa Utara. 
Listiyani, R. (2015). Efektivitas Implementasi Kebijakan penggunaan Dana DesaTahun Anggara 201 Di Desa Gunungpring Kecamatan Muntilan Kabupaten Magelang. 1-12.

Mustanir, A., \& Darmiah. (2016). Implementasi kebijakan dana desa dan partisipasi masyarakat dalam pembangunan di desa teteaji kecamatan tellu limpoe kabupaten sidenreng rappang. Jurnal Politik Profetik, 4(2), 225238.

Nazhiroh, R. D. (2018). Analisis Efektivitas Program Alokasi Dana Desa Pada Pemberdayaan Ekonomi Perspektif Ekonomi Islam. Universitas Islam Negeri Raden Intan.

Yunita, A. (2019). Evaluasi Akuntabilitas dan Efektivitas Pengelolaan Dana Desa Di Kabupaten Bangka dan Kabupaten Belitung;:Tirtayasa Ekonomika, 14(1),66-78.

Zakiah, S. (2019). Efektivitas pemanfaatan dana desa dalam menunjang pembangunan Desa di desa bontomanai kecamatan bungaya kabupaten gowa tahun anggaran 2017- 2018. Sekolah Tinggi Ilmu Ekonomi Nobel Indonesia 